\title{
PENGARUH KARAKTERISTIK INDIVIDU DAN ETOS KERJA TERHADAP KINERJA PEGAWAI PADA SEKRETARIAT DAERAH KABUPATEN SIMALUNGUN
}

\author{
Roy Sahputra Saragih, S.Pd., MM ${ }^{1)}$, Nancy Florida Siagian, S.Pd., MM ${ }^{2)}$ \\ Sekretaris, Politeknik Bisnis Indonesia Murni Sadar email: \\ roysahputra31@yahoo.com \\ Komputerisasi Akuntansi, Politeknik Bisnis Indonesia Murni Sadar email: \\ siagiannancyflorida@gmail.com
}

\begin{abstract}
This study aims to determine and analyze (1) the effect of individual characteristics on employee performance; (2) the influence of work ethic on employee performance; (3) the influence of individual characteristics and work ethic on employee performance. The method used in this research is to use quantitative analysis methods. Sampling in this study using the Slovin method. The number of samples in this study were 70 employees of the Regional Secretariat of Simalungun Regency From the research results, the following results can be obtained: (a) the multiple regression results are $Y^{\prime} Y^{\prime}=10.107+0.330 X 1+0.504 X 2 ;(b)$ the results of the $t$ test (partial) show that each individual characteristic variable (X1) and work ethic (X2) have a significant effect on employee performance $(Y)$, where the value of $t$ count $>t$ table $(0.235)$ and the value of 'Sig' respectively -Each individual characteristic variable (X1) is 0.014 and work ethic (X2) is $0.001<0.05$. (c) the output model summary ( $R$ Square value) is 0.282 , meaning that variations in employee performance can be explained by variations in individual characteristics (X1) and work ethic (X2)\% and the rest is explained by other variables not examined. (d) From the calculation of the Fcount value of 13,146> the FTabel value of 3.13 or if it is seen from the sig 'value of 0.000 $<0.05$ then $\mathrm{HO}$ is rejected.
\end{abstract}

Keywords: Individual Characteristics, Work Ethic and Employee Performance.

\section{PENDAHULUAN}

Manusia merupakan unsur penting didalam kehidupan. Baik dalam kehidupan individu, masyarakat, maupun perusahaan atau organisasi. Manusia sebagai hal yang sangat berpengaruh dalam kegiatan sehari-hari. Peran manusia juga penting didalam sebuah organisasi, dengan adanya kehadiran manusia maka kegiatan dan proses yang dilakukan saat bekerja akan dapat terlaksana. Kehadiran sumber daya manusia tersebut digunakan untuk mencapai tujuan yang diiinginkan organisasi. Sebuah perusahaan atau organisasi harus mampu memanfaatkan sumber daya yang dimiliki secara optimal. Salah satunya adalah dengan meningkatkan kualitas sumber daya manusianya. Hal yang harus dilakukan perusahaan adalah dengan memiliki manajemen sumber daya manusia yang mampu menciptakan kondisi yang mendorong dan memungkinkan karyawan untuk mengembangkan kualitas karyawan yang dimiliki. Kualitas karyawan sangat erat hubungannya kenerja dari fungsi sumber daya manusia dalam suatu perusahaan terkait dengan rekrutmen tenaga kerja, pelatihan, penempatan, evaluasi kinerja, (Febrianty et al., 2020). Semua kemampuan yang dimiliki karyawan dapat berpengaruh untuk perkembangan organisasi tersebut, (Sirait, 2019b).

Salah satu faktor yang mempengaruhi kinerja pegawai adalah bagaimna karaekteristik individu tersebut. Keberadaan manusia merupakan sumber daya yang paling istimewa,keistimewaan yang ada pada manusia 
adalah satu-satunya sumber daya yang mempunyai pikiran, perasaan, dan kepribadian yang berbeda-beda. Baik buruknya karakteristik individu pegawai tergantung bagaimana mereka mengaplikasikannya.

Perbedaan karakteristik individu dapat menerangkan penyebab berbedanya kinerja karyawan yang satu dengan yang lain. Karakteristik merupakan ciri, tabiat, kebiasaan atau sifat yang membedakan seseorang dengan yang lain serta berkemampuan dalam mengarahkan tindakan seorang individu.

Selain karakteristik individu ada juga faktor yang berpengaruh langsung pada pegawai dan tidak dapat dipisahkan dalam tercapainya suatu tujuan perusahaan yaitu etos kerja. Etos kerja dikatakan sebagai faktor penentu dari keberhasilan individu, kelompok, institusi dan juga yang terluas ialah bangsa dalam mencapai tujuannya. Pada pelaksanaan administrasi publik juga dipengaruhi oleh etos kerja yang dimiliki oleh pejabat-pejabat publik dalam tugasnya menyelenggarakan kebutuhan masyarakat.

Etos kerja merupakan yang hal utama dalam melaksanakan pekerjaan untuk mencapai keunggulan budi dan keunggulan karakter yang menghasilkan kerja dan kinerja yang unggul pula. Tentunya, keunggulan tersebut berasal dari buah ketekunan seorang manusia Mahakarya. Kemampuan menghayati pekerjaan menjadi sangat penting sebagai upaya menciptakan keunggulan. Intinya, bahwa saat kita melakukan suatu pekerjaan maka hakikatnya kita sedang melakukan suatu proses pelayanan. Menghayati pekerjaan sebagai pelayanan memerlukan kemampuan transendensi yang bersifat melampaui ruang gerak manusia yang kecil.

Sampai saat ini aparat birokrasi pemerintah belum sepenuhnya melaksanakan tugas sesuai dengan fungsi yang dibebankan kepadanya berdasarkan norma-norma yang ditetapkan dan diharapkan oleh masyarakat. Kondisi ini dapat dilihat melalui berbagai penyimpangan yang terjadi sehingga semakin lama semakin parah dan berakibat pada tingkat kepercayaan masyarakat terhadap pemerintah menurun. Kondisi ini diperparah dengan krisis multi dimensi yang mengakibatkan krisis ekonomi nasional dan semuanya bermuara pada krisis kepercayaan.

Rendahnya kinerja birokrasi publik sangat dipengaruhi oleh budaya paternalisme yang masih sangat kuat, yang cenderung mendorong pejabat birokrasi untuk lebih berorientasi pada kekuasaan daripada pelayanan, menempatkan dirinya sebagai penguasa dan memperlakukan para pengguna jasa sebagai obyek pelayanan yang membutuhkan bantuannya. Disamping itu, rendahnya kinerja juga disebabkan oleh sistem pembagian kekuasaan yang cenderung memusat pada pimpinan. Struktur birokrasi yang hierarkis mendorong adanya pemusatan kekuasaan dan wewenang pada atasan sehingga pejabat birokrasi yang langsung berhubungan dengan para pengguna jasa sering tidak memiliki wewenang yang memadai untuk merespons dinamika yang berkembang dalam penyelenggaraan pelayanan.

Bagi Sekretariat Daerah Kabupaten Simalungun sebagai organisasi yang mengemban fungsi koordinasi dan pelayanan teknis administrasi kepada seluruh perangkat/instansi vertikal pemerintah daerah maka penilaian kinerja bagi aparatur organisasi memiliki arti yang sangat penting terutama dalam upaya melakukan perbaikan-perbaikan pada masa yang akan datang. Penilaian kinerja bagi aparatur berguna untuk menilai kuantitas, kualitas dan efisiensi pelayanan, motivasi, dan guna penyesuaian anggaran organisasi. Tetapi persoalannya, apakah penilaian yang dilakukan telah menggambarkan kinerja yang sebenarnya. Hal ini akan sangat ditentukan oleh ketajaman dalam menentukan cakupan, cara dan indikatorindikator yang digunakan. Suatu penilaian yang menggunakan cakupan, cara dan indikator yang sangat terbatas akan memberikan hasil yang sangat terbatas pula dan berarti kurang menggambarkan keadaan yang sebenarnya. Selama ini, penilaian secara sistematik terhadap kinerja aparatur belum menjadi tradisi, sehingga berakibat pada munculnya perdebatan yang tidak terselesaikan ketika terjadi hasil penilaian yang berbeda antara pihak yang satu dengan lainnya.

\section{Rumusan Masalah}


Dalam penelitian ini berdasarkan latar belakang yang ada maka pokok masalah yang dihadapi diuraikan sebagai berikut ini.

a. Bagaimana karakteristik individu berpengaruh terhadap kinerja pegawai?

b. Bagaimana etos kerja berpengaruh terhadap kinerja kinerja pegawai?

c. Bagaimana karakteristik individu dan etos kerja secara bersama-sama berpengaruh terhadap kinerja pegawai?

\section{Tujuan Penelitian}

1. Untuk mengetahui bagaimana pengaruh karakteristik individu terhadap kinerja pegawai.

2. Untuk mengetahui bagaimana pengaruh etos kerja terhadap kinerja pegawai.

3. Untuk mengetahui pengaruh karakteristik individu dan etos kerja secara bersama terhadap kinerja pegawai.

\section{LANDASAN TEORI}

Menurut (Badeni et al., 2014), Karakteristik individu merupakan ciri-ciri individual yang mencakup usia, jenis kelamin, status, jumlah tanggungan, masa kerja, kemampuan dan kepribadian.

(Thoha, 2016) menyatakan bahwa individu membawa kedalam tatanan organisasi, kemampuan, kepercayaan pribadi, pengharapan kebutuhan dan pengalaman masa lalunya. Ini semua adalah karakteristik yang dimiliki individu dan karakteristik ini akan memasuki suatu lingkungan baru, yakni organisasi. Sumber daya yang terpenting dalam suatu organisasi adalah sumber daya manusia, setiap manusia mempunyai karakteristik individu yang berbeda-beda antara yang satu dengan yang lainnya. Masa depan seorang individu dalam organisasi tidak bergantung pada kinerja saja. Manajer juga menggunakan ukuran subyektif yang bersifat pertimbangan. Apa yang dipersepsikan oleh penilai sebagai karakter/prilaku karyawan yang baik atau buruk akan mempengaruhi penilaian.

Dari pendapat para ahli diatas, maka karakteristik individu dapat dilihat dari kemampuan, karakteristik-karakteristik biografis, pembelajaran, sikap, kepribadian, persepsi, dan nilai. Sumber daya yang terpenting dalam organisasi adalah sumber daya manusia, orang-orang yang memberikan tenaga, bakat, kreativitas, dan usaha mereka kepada organisasi agar suatu organisasi dapat tetap eksistensinya.

Menurut (Ginting, 2016) etos kerja merupakan semangat kerja yang menjadi cirri khas seseorang atau sekelompok orang yang bekerja, yang berlandaskan etika dan perspektif kerja yang diyakini, dan diwujudkan melalui tekad dan perilaku konkret di dunia kerja.

Menurut (Purba, 2015) etos kerja adalah kebiasaan yang berkenaan dengan kegiatan seseorang dalam melakukan pekerjaannya yang meliputi suka bekerja keras, dapat menerima perubahan, bertindak rasional, mematuhi aturan, dapat dipercaya dan semangat dalam bekerja.

Lebih lanjut (Octarina, 2013) mendefinisikan etos kerja adalah sebagai doktrin tentang kerja yang diyakini oleh seseorang atau sekelompok orang sebagai baik dan benar yang mewujud nyata secara khas dalam perilaku kerja mereka.

Dari beberapa definisi yang telah dijabarkan dari beberapa tokoh di atas, dapat disimpulkan bahwa etos kerja adalah watak atau karakter individu atau kelompok tertentu tentang pemahaman terhadap nilai-nilai yang mendefinisikan pekerjaan sebagai sesuatu yang penting, yang muncul dalam perilaku kerja atas kehendak dan kesadaran sendiri yang didasari oleh orientasi terhadap nilai dan budaya kerja serta terikat dengan kualitas hidup, moral, estetika dan perasaan dalam upaya untuk mencapai kualitas kerja yang sesempurna mungkin dan meningkatkan kualitas kehidupannya. Etos kerja seseorang dipengaruhi oleh motivasinya. Motivasi merupakan kegiatan yang mengakibatkan, menyalurkan, dan memelihara perilaku seseorang, (Sirait, 2019a).

Menurut (Edison \& others, 2016) kinerja adalah hasil dari suatu proses yang mengacu dan diukur selama periode waktu tertentu berdasarkan ketentuan atau kesepakatan yang telah ditetapkan sebelumnya.

Selanjutnya Menurut (Zulkifli et al., 2014) kinerja adalah kesuksesan seseorang dalam 
melaksanakan tugas, hasil kerja yang dapat dicapai oleh seseorang atau sekelompok orang dalam suatu organisasi sesuai dengan wewenang dan tanggung jawab masing-masing atau tentang bagaimana seseorang diharapkan dapat berfungsi dan berperilaku sesuai dengan tugas yang telah dibebankan kepadanya serta kuantitas, kualitas dan waktu yang digunakan dalam menjalankan tugas.

Jadi dapat disimpulkan bahwa kinerja adalah suatu keadaan pelaksanaan kerja di dalam suatu instansi yang didasarkan pada perasaan emosional seorang karyawan. Hal ini akan tampak dari sikap karyawan terhadap aspek-aspek yang dihadapinya di lingkungan kerja yang menyangkut penyesuaian diri yang sehat termasuk di dalamnya gaji, kondisi fisik, dan psikologis maupun aturan hukum yang ada. Karyawan atau pegawai adalah bagian dari proses produksi, sehingga diperlukan etos kerja yang baik untuk menghasilkan kinerja yang baik, (Sirait, 2019a).

Untuk mengukur kinerja organisasi atau kinerja aparatur, sebagaimana disebutkan oleh (Dwiyanto, 2018) mengatakan bahwa tiga konsep, yaitu responsiveness, responsibility dan accountability.

\section{Hipotesis}

Berkenaan dengan masalah ini (Arikunto, 2006) menyatakan bahwa hipotesis dapat diartikan sebagai suatu jawaban yang bersifat sementara terhadap permasalahan penelitian sampai terbukti melalui data yang terkumpul.

Berdasarkan deskripsi dan kerangka berpikir yang telah diuraikan sebelumnya, maka dapat dirumuskan suatu hipotesis sebagai berikut :

1. Karakteristik individu berpengaruh positif dan signifikan terhadap kinerja pegawai.

2. Etos Kerja berpengaruh positif dan signifikan terhadap kinerja pegawai.

3. Karakteristik individu dan Etos Kerja berpengaruh positif dan signifikan terhadap kinerja pegawai.

\section{METODE PENELITIAN} Desain Penelitian

Penelitian Ini didasarkan pada hubungan kasual yang bersifat sebab akibat, jadi ada variabel independen (variabel yang mempengaruhi), variabel dependen (variabel yang dipengaruhi), dan variabel mediasi (variabel yang mempengaruhi hubungan antara variabel independen dengan dependen).

\section{Instrumen Penelitian}

Penentuan skoring ilmiah secara umum berpedoman pada aturan Likert dan Gutman. Kedua metode ini memenuhi kaidah ilmiah dalam penentuan dan penilaian skoring suatu instrumen penelitian. Dalam hal ini penulis memakai metode Likert. Pendekatan dengan skala Likert digunakan untuk mengukur sikap, pendapat dan persepsi seseorang atau sekelompok orang tentang fenomena sosial.

Untuk analisis secara kuantitatif, maka altenatif jawaban tersebut dapat diberi skor dair nilai 1 sampai 5 sebagai berikut :

- Sangat Setuju (SS) di beri skor 5

- Setuju (S) di beri skor 4

- $\quad$ Netral (N) di beri skor 3

- Tidak Setuju (TS) di beri skor 2

- Sangat Tidak Setuju (STS) di beri skor 1

\section{Lokasi Dan Waktu Penelitian}

Untuk melakukan suatu penelitian tidak pernah terlepas dari tempat atau lokasi digunakan untuk mengumpulkan data atau informasi. Sesuai dengan judul yang dikemukakan sebelumnya, maka dalam pelaksanaan penelitian ini, penulis memilih lokasi atau tempat penelitian di Sekretariat Daerah Kabupaten Simalungun.

\section{Uji Normalitas Data}

Normalitas bertujuan untuk menguji apakah dalam model regresi, dependen variabel dan independent variabel keduanya mempunyai distribusi normal ataukah tidak. Model regresi yang baikadalah memiliki distribusi data normal atau mendekati normal (Ghozali, 2006).

Mendeteksi dengan melihat penyebaran data (titik) pada sumbu

diagonal dari grafik normal P-P Plot. Dasar pengambilan keputusan:

a. Jika data menyebar di sekitar garis diagonal dan mengikuti arah garis diagonal, atau grafik histogramnya menunjukkan pola 
distribusi normal, maka model regresi memenuhi asumsi normalitas.

b. Jika data menyebar jauh dari garis diagonal dan atau tidak mengikuti arah garis diagonal, atau grafik histogram tidak menunjukkan pola distribusi normal, maka model regresi tidak memenuhi asumsi normalitas.

\section{Uji Hipotesis}

\section{a. Uji t}

Untuk menentukan tingkat signifikan secara parsial antara masing-masing variabel bebas dengan variabel terikat, maka hipotesis harus diuji-t pada taraf signifikan sebesar $\alpha=5$ $\%$ secara dua arah. Selanjutnya diambil keputusan, yaitu :

- Jika nilai signifikansi pengujian > 0,05 $(\alpha=5 \%)$, maka Ho diterima dan Ha ditolak, sehingga hipotesis yang dirumuskan tidak terbukti kebenarannya.

- Jika nilai signifikansi pengujian < 0,05 $(\alpha=5 \%)$, maka Ho ditolak dan Ha diterima, sehingga hipotesis yang dirumuskan terbukti kebenarannya.

\section{b. Uji F}

Sehubungan dengan uji regresi linier berganda, uji hipotesis ditentukan dengan menggunakan uji F. Pengujian ini dilakukan untuk menentukan signifikan pengaruh variabel-variabel secara simultan terhadap variabel terikat. Pengujian ini akan membandingkan nilai signifikan dari hasil pengujian data dengan membandingkan nilai signifikan yang telah ditetapkan sebesar 0.05 atau $5 \%$.

\section{HASIL DAN PEMBAHASAN}

Dalam evaluasi data ini penulis akan melakukan pengujian hipotesis, baik secara partial ataupun secara simultan. Selanjutnya untuk mempermudah dalam evaluasi data ini, maka penulis mencari nilai-nilai yang dibutuhkan dengan menggunakan perangkat lunak komputer Program SPSS Vs. 22 for windows dengan hasil sebagai berikut :

\section{Uji Regresi Berganda}

Uji ini dapat dilakukan dengan mambandingkan $\mathrm{t}$ hitung dengan $\underline{\mathrm{t} \text { tabel atau }}$ dengan melihat kolom signifikansi pada masing-masing thitung.

\section{Tabel 1. Hasil Uji Regresi Berganda}

\begin{tabular}{|c|c|c|c|c|c|}
\hline \multirow[b]{2}{*}{ Model } & \multicolumn{2}{|c|}{$\begin{array}{l}\text { Unstandardized } \\
\text { Coefficients }\end{array}$} & \multirow{2}{*}{$\begin{array}{c}\begin{array}{c}\text { Standardized } \\
\text { Coefficients }\end{array} \\
\text { Beta } \\
\end{array}$} & \multirow[b]{2}{*}{$\mathrm{t}$} & \multirow[b]{2}{*}{ Sig. } \\
\hline & $\mathrm{B}$ & $\begin{array}{l}\text { Std. } \\
\text { Error }\end{array}$ & & & \\
\hline $1 \quad$ (Constant) & 10.107 & 3.264 & & 3.097 & .003 \\
\hline Karakteristik Individu & .330 & .130 & .276 & 2.532 & .014 \\
\hline Etos Kerja & .504 & .147 & .374 & 3.431 & .001 \\
\hline
\end{tabular}

a.Dependent Variable: Kinerja Pegawai

Sumber : Hasil Penelitian-2020 (Data diolah)

Berdasarkan pengujian diatas, didapat persamaan :

$$
\begin{aligned}
& Y^{\prime}=a+b_{1} X_{1}+b_{2} X_{2} \\
& Y^{\prime}=10,107+0,330 X_{1}+0,504 X_{2}
\end{aligned}
$$

Persamaan regresi di atas dapat dijelaskan sebagai berikut:

a) Konstanta sebesar 10,107; artinya jika karakteristik individu $\left(\mathrm{X}_{1}\right)$ dan etos kerja $\left(\mathrm{X}_{2}\right)$ nilainya adalah 0 , maka kinerja pegawai (Y') nilainya adalah 10,107 . b) Koefisien regresi variabel jika karakteristik individu $\left(\mathrm{X}_{1}\right)$ sebesar 0,330; artinya jika variabel independen lain nilainya tetap dan jika karakteristik individu mengalami kenaikan $1 \%$, maka kinerja pegawai (Y) akan mengalami peningkatan sebesar 0,380. Koefisien bernilai positif artinya terjadi hubungan positif antara jika karakteristik individu dengan kinerja pegawai, semakin naik jika 
karakteristik individu maka semakin naik kinerja pegawai.

c. Koefisien regresi variabel etos kerja $\left(\mathrm{X}_{2}\right)$ sebesar 0,570; artinya jika variabel independen lain nilainya tetap dan etos kerja mengalami kenaikan 1\%, maka kinerja pegawai (Y) akan mengalami peningkatan sebesar 0,504. Koefisien bernilai positif artinya terjadi hubungan positif antara etos kerja dengan kinerja pegawai, semakin naik etos kerja maka semakin meningkat kinerja pegawai.

Tabel 2. Hasil Uji Hipotesis

\begin{tabular}{|c|c|c|c|c|c|c|c|c|c|c|}
\hline \multirow[b]{3}{*}{ Model } & \multicolumn{8}{|c|}{ Coefficients $^{a}$} & & \\
\hline & \multicolumn{2}{|c|}{$\begin{array}{c}\text { Unstandardized } \\
\text { Coefficients }\end{array}$} & $\begin{array}{c}\text { Standardi } \\
\text { zed } \\
\text { Coefficie } \\
\text { nts } \\
\end{array}$ & & & \multicolumn{3}{|c|}{ Correlations } & \multicolumn{2}{|c|}{$\begin{array}{c}\text { Collinearity } \\
\text { Statistics }\end{array}$} \\
\hline & $\mathrm{B}$ & $\begin{array}{l}\text { Std. } \\
\text { Error }\end{array}$ & Beta & $\mathrm{t}$ & Sig. & $\begin{array}{c}\text { Zero } \\
- \\
\text { order }\end{array}$ & Partial & Part & Tolerance & VIF \\
\hline \multirow{3}{*}{$\begin{array}{ll}1 & \text { (Constant) } \\
\text { Karakteristik } \\
\text { Individu } \\
\text { Etos Kerja }\end{array}$} & 10.107 & 3.264 & & 3.097 & .003 & & & & & \\
\hline & .330 & .130 & .276 & 2.532 & .014 & .395 & .296 & .262 & .900 & 1.111 \\
\hline & .504 & .147 & .374 & 3.431 & .001 & .462 & .387 & .355 & .900 & 1.111 \\
\hline
\end{tabular}

a. Dependent Variable: Kinerja Pegawai

\section{Sumber : Hasil Penelitian-2020 (Data diolah)}

Berdasarkan tabel di atas maka dapat dilihat :

a) Nilai t hitung untuk variabel karakteristik individu $\left(\mathrm{X}_{1}\right)$ adalah 2.532 sementara nilai $\mathrm{t}$ tabel (dilihat pada uji dua arah pada kolom 0,05 atau tarap 5\%) terdapat nilai antara $1.980 \& 2.000$ yang artinya nilai $t$ hitung variabel karakteristik individu $\left(X_{1}\right)$ lebih besar dari nilai $\mathrm{t}$ tabel dan nilai 'Sig' karakteristik individu $\left(\mathrm{X}_{1}\right) \quad 0,014$ yang artinya variabel karakteristik individu $\left(\mathrm{X}_{1}\right)$ memiliki nilai 'Sig' $<0,05$, maka disimpulkan bahwa terdapat pengaruh yang signifikan antara karakteristik individu $\left(\mathrm{X}_{1}\right)$ terhadap kinerja pegawai (Y).

b) Nilai thitung untuk variabel etos kerja $\left(\mathrm{X}_{2}\right)$ adalah 3.431 sementara nilai $\mathrm{t}$ tabel (dilihat pada uji dua arah pada kolom 0,05 atau tarap 5\%) terdapat nilai antara 1.980 $\& 2.000$ yang artinya nilai t hitung variabel etos kerja lebih besar dari nilai t tabel serta nilai 'Sig' etos kerja 0,001 yang artinya variabel etos kerja memiliki nilai 'Sig' $<0,05$, maka disimpulkan bahwa terdapat pengaruh yang signifikan antara etos kerja $\left(\mathrm{X}_{2}\right)$ terhadap kinerja pegawai (Y).

c) Nilai t hitung untuk masing masing variabel karakteristik individu dan etos kerja adalah 2.532 dan 3.431 sementara nilai $t$ tabel (dilihat pada uji dua arah pada kolom 0,05 atau tarap 5\%) terdapat nilai anatar 1.980 \& 2.000 yang artinya nilai $\mathrm{t}$ hitung variabel karakteristik individu $\left(\mathrm{X}_{1}\right)$ dan etos kerja $\left(\mathrm{X}_{2}\right)$ lebih besar dari nilai $\mathrm{t}$ tabel serta nilai 'Sig' masing-masing variabel karakteristik individu $\left(\mathrm{X}_{1}\right)$ dan etos kerja $\left(\mathrm{X}_{2}\right)$ adalah 0,002 dan 0.000 yang artinya variabel karakteristik individu $\left(\mathrm{X}_{1}\right)$ dan etos kerja $\left(\mathrm{X}_{2}\right)$ memiliki nilai 'Sig' $<0,05$. Maka disimpulkan bahwa terdapat pengaruh yang signifikan antara karakteristik individu $\left(\mathrm{X}_{1}\right)$ dan etos kerja $\left(\mathrm{X}_{2}\right)$ terhadap kinerja pegawai (Y).

\section{Koefisien Determinasi $\left(\mathbf{R}^{2}\right)$}

Koefisien determinasi mengukur seberapa besar pengaruh variabel independen secara keseluruhan terhadap naik turunnya variasi nilai variabel dependen.

Tabel 3. Koefisien Determinasi 


\begin{tabular}{|l|c|c|c|c|}
\hline Model & $\mathrm{R}$ & $\begin{array}{c}\mathrm{R} \\
\text { Square }\end{array}$ & $\begin{array}{c}\text { Adjusted } \\
\mathrm{R} \text { Square }\end{array}$ & $\begin{array}{c}\text { Std. Error of the } \\
\text { Estimate }\end{array}$ \\
\hline 1 & $.531^{\mathrm{a}}$ & .282 & .261 & 4.786 \\
\hline
\end{tabular}

Sumber : Hasil Penelitian-2020 (Data diolah)

Pada output Model Summary dalam Tabel nilai $\mathrm{R}$ Square sebesar 0,282 , berarti variasi kinerja pegawai dapat dijelaskan oleh variasi karakteriatik individu dan etos kerja sebesar $28,2 \%$ dan selebihnya dijelaskan oleh variabel lain yang tidak diteliti.

Uji F
Uji F digunakan untuk mengetahui pengaruh variabel bebas secara bersama-sama (simultan) terhadap variabel terikat. Signifikan berarti hubungan yang terjadi dapat berlaku untuk populasi.

Tabel 4. Hasil Uji F ANOVA $^{a}$

\begin{tabular}{|c|c|c|c|c|c|}
\hline Model & $\begin{array}{c}\text { Sum of } \\
\text { Squares }\end{array}$ & df & $\begin{array}{c}\text { Mean } \\
\text { Square }\end{array}$ & $\mathrm{F}$ & Sig. \\
\hline 1 Regression & 602.568 & 2 & 301.284 & 13.156 & $.000^{\mathrm{b}}$ \\
\hline Residual & 1534.417 & 67 & 22.902 & & \\
\hline Total & 2136.986 & 69 & & & \\
\hline
\end{tabular}

a. Dependent Variable: Kinerja Pegawai

b. Predictors: (Constant), Etos Kerja, Karakteristik Individu

Dari penghitungan tabel didapat nilai $F_{\text {hitung }}$ sebesar 13.156. Dengan tingkat signifikansi sebesar 5\% dan $\mathrm{df}_{1}(\mathrm{k}-1)=3-1=$ 2 dan $\mathrm{df}_{2}(\mathrm{n}-\mathrm{k}-1)=70-2-1=67$, didapat nilai $\mathrm{F}_{\text {Tabel }}=3,13$. Karena nilai $\mathrm{F}_{\text {hitung }}(13.156)>$ nilai $\mathrm{F}_{\text {Tabel }}(3,13)$ atau jika dilihat dari nilai sig' sebesar $0,000<0.05$ maka $\mathrm{H}_{0}$ ditolak. Sehingga dapat disimpulkan bahwa aspek variabel karakteriatik individu $\left(\mathrm{X}_{1}\right)$ dan etos kerja $\left(\mathrm{X}_{2}\right)$ secara simultan berpengaruh signifikan terhadap kinerja pegawai (Y).

\section{Pengaruh Variabel}

\section{Karakteristik Individu Berpengaruh Positif Terhadap Kinerja Pegawai}

Pada tabel 2 karakteristik individu memiliki nilai 'Sig' sebesar 2.532 sementara nilai $t$ tabel (dilihat pada uji dua arah pada kolom 0,05 atau tarap 5\%) terdapat nilai antara $1.980 \& 2.000$ yang artinya nilai $\mathrm{t}$ hitung variabel karakteristik individu $\left(\mathrm{X}_{1}\right)$ lebih besar dari nilai $\mathrm{t}$ tabel dan nilai 'Sig' karakteristik individu $\left(\mathrm{X}_{1}\right)$ 0,014 yang artinya variabel karakteristik individu $\left(\mathrm{X}_{1}\right)$ memiliki nilai 'Sig'
$<0,05$, maka disimpulkan bahwa terdapat pengaruh yang signifikan antara karakteristik individu $\left(\mathrm{X}_{1}\right)$ terhadap kinerja pegawai $(\mathrm{Y})$. Hal ini menjawab bahwa pertanyaan pada hipotesis 1 diterima dan dinyatakan karakteristik individu berpengaruh positif terhadap kinerja pegawai.

\section{Etos Kerja Berpengaruh Positif Terhadap Kinerja Pegawai}

Pada tabel 2 Nilai t hitung untuk variabel etos kerja $\left(\mathrm{X}_{2}\right)$ adalah 3.431 sementara nilai t tabel (dilihat pada uji dua arah pada kolom 0,05 atau tarap 5\%) terdapat nilai antara $1.980 \&$ 2.000 yang artinya nilai $t$ hitung variabel etos kerja lebih besar dari nilai $t$ tabel serta nilai 'Sig' etos kerja 0,001 yang artinya variabel etos kerja memiliki nilai 'Sig' <

0,05, maka disimpulkan bahwa terdapat pengaruh yang signifikan antara etos kerja $\left(\mathrm{X}_{2}\right)$ terhadap kinerja pegawai (Y).

\section{Karakteristik Individu Dan Etos Kerja Secara Bersama Sama Berpengaruh Positif Terhadap Terhadap Kinerja Pegawai}

Nilai $t$ hitung untuk masing masing variabel karakteristik individu dan etos kerja 
adalah 2.532 dan 3.431 sementara nilai t tabel (dilihat pada uji dua arah pada kolom 0,05 atau tarap 5\%) terdapat nilai anatar $1.980 \& 2.000$ yang artinya nilai $\mathrm{t}$ hitung variabel karakteristik individu $\left(\mathrm{X}_{1}\right)$ dan etos kerja $\left(\mathrm{X}_{2}\right)$ lebih besar dari nilai $\mathrm{t}$ tabel serta nilai 'Sig' masing-masing variabel karakteristik individu $\left(\mathrm{X}_{1}\right)$ dan etos kerja $\left(\mathrm{X}_{2}\right)$ adalah 0,002 dan 0.000 yang artinya variabel karakteristik individu $\left(\mathrm{X}_{1}\right)$ dan etos kerja $\left(\mathrm{X}_{2}\right)$ memiliki nilai 'Sig' $<0,05$. Maka disimpulkan bahwa terdapat pengaruh yang signifikan antara karakteristik individu $\left(\mathrm{X}_{1}\right)$ dan etos kerja $\left(\mathrm{X}_{2}\right)$ terhadap kinerja pegawai $(\mathrm{Y})$. Hal ini menjawab bahwa pertanyaan pada hipotesis 3 diterima dan dinyatakan karakteristik individu dan etos kerja bersama sama berpengaruh positif terhadap kinerja pegawai.

\section{KESIMPULAN}

Dari pembahasan penelitian yang telah diuraikan, maka dapat ditarik kesimpulan sebagai berikut :

1. Terdapat pengaruh yang positf dan signifikan antara karakteristik individu terhadap kinerja pegawai Sekretariat Daerah Kabupaten Simalungun. Dengan demikian Ha diterima dan Ho diterima.

2. Terdapat pengaruh yang signifikan antara etos kerja terhadap Kinerja Pegawai Sekretariat Daerah Kabupaten Simalungun. Dengan demikian $\mathrm{Ha}$ diterima dan $\mathrm{Ho}$ diterima.

3. Terdapat pengaruh yang signifikan antara karakteristik individu dan etos kerja terhadap Kinerja Pegawai Sekretariat Daerah Kabupaten Simalungun. Dengan demikian Ha diterima dan Ho diterima.

\section{Saran}

Dari kesimpulan diatas, untuk mengantisipasi hal tersebut dan untuk mencapai maksud dan tujuan peningkatan Kinerja Pegawai Sekretariat Daerah Kabupaten Simalungun, maka disarankan sebagai berikut :

1. Sehubungan dengan peningkatan kinerja pegawai, pemimpin hendaknya dapat memotivasi dan memberi kesempatan seluas-luasnya untuk dapat bekerja dan berkarya sesuai dengan kemampuan yang telah mereka miliki.

2. Mempertimbangkan bahwa karakteristik dan etos kerja berpengaruh positif terhadap produktivitas maka baik bagi organisasi untuk membantu pegawai agar dapat meningkatkan etos kerja yang tinggi misalnya pimpinan membantu pegawai mengembangkan ketrampilan dalam manajemen diri dan menjadi teladan bagi para karyawan seperti halnya seorang pimpinan harus memiliki sikap kemandirian di dalam bekerja, memiliki komitmen untuk bekerja keras, serta dapat menggunakan waktu secara efisien dan produktif.

\section{REFERENSI}

Arikunto, S. (2006). Metodelogi penelitian. Yogyakarta: Bina Aksara.

Badeni, B., Saparahayuningsih, S., \& Makmurtomo, A. (2014). Model Pendidikan Nilai Budi Pekerti Berbasis Kearifan Lokal bagi Siswa Sekolah dasar. Sekolah Dasar: Kajian Teori Dan Praktik Pendidikan, 23(1).

Dwiyanto, A. (2018). Manajemen Pelayanan Publik: Peduli Inklusif Dan Kolaborasi. UGM PRESS.

Edison, A. A., \& others. (2016). PERANCANGAN PENGUKURAN KINERJA DENGAN METODE BALANCED SCORECARD DAN PENENTUAN PRIORITAS ANALYTICAL HIERARCHY PROCESS (STUDI KASUS PADA PT. ANDROMEDA GALACTICORP SURABAYA). UNIVERSITAS AIRLANGGA.

Febrianty, F., Nurmiati, N., Parinduri, L., Sirait, S., Leuwol, N. V., Julyanthry, J., Dharma, E., \& Sudarso, A. (2020). Pengantar Bisnis: Etika, Hukum \& Bisnis Internasional. Yayasan Kita Menulis.

Ghozali, I. (2006). Aplikasi analisis multivariate dengan program SPSS. Badan Penerbit Universitas Diponegoro.

Ginting, D. (2016). Etos Kerja-Panduan Menjadi Karyawan Cerdas. Elex Media Komputindo.

Octarina, A. (2013). Pengaruh Etos Kerja Dan Disiplin Kerja Terhadap Kinerja Pegawai 
Pada Dinas Kebudayaan Pariwisata Pemuda Dan Olahraga Kabupaten Sarolangun. Manajemen S-1, 1(1).

Purba, K. (2015). Pengaruh Karakteristik Individu, Gaya Kepemimpinan Dan Lingkungan Kerja Terhadap Etos Kerja Karyawan Pada Pt. Bank Mandiri (Persero) Tbk, Unit Performance And Budgeting Kantor Wilayah I Medan.

Sirait, S. (2019a). Motivasi sebagai faktor peningkatan kinerja kepolisian. $E K \& B I$, 2(1), 167-177.

Sirait, S. (2019b). MOTIVASI SEBAGAI FAKTOR PENINGKATAN KINERJA KEPOLISIAN. Jurnal Ekonomi Dan Bisnis (EK\&BI), 2(1), 167-177.

Thoha, M. (2016). Kepemimpinan dalam manajemen. PT RajaGrafindo Persada.

Zulkifli, M., Darmawan, A., \& Sutrisno, E. (2014). Motivasi Kerja, Sertifikasi, Kesejahteraan dan Kinerja Guru. Persona: Jurnal Psikologi Indonesia, 3(02). 